\title{
Correction to: Secukinumab: A Review in Ankylosing Spondylitis
}

\author{
Hannah A. Blair ${ }^{1}$
}

Published online: 11 March 2019

(c) Springer Nature 2019

\section{Correction to: Drugs}

https://doi.org/10.1007/s40265-019-01075-3

The article Secukinumab: A Review in Ankylosing Spondylitis, written by Hannah A. Blair, was originally published Online First without open access. After online publication Novartis Pharma AG requested that the article be Open Choice to make the article an open access publication. Post-publication open access was funded by Novartis Pharma AG. The article is forthwith distributed under the terms of the Creative Commons Attribution-NonCommercial 4.0 International License (http://creativecommons.org/ licenses/by-nc/4.0/), which permits any noncommercial use, duplication, adaptation, distribution and reproduction in any medium or format, as long as you give appropriate credit

to the original author(s) and the source, provide a link to the Creative Commons license and indicate if changes were made.

The original article has been update.

Open Access This article is distributed under the terms of the Creative Commons Attribution 4.0 International License (http://creativecommons.org/licenses/by/4.0/), which permits unrestricted use, distribution, and reproduction in any medium, provided you give appropriate credit to the original author(s) and the source, provide a link to the Creative Commons license, and indicate if changes were made.

The original article can be found online at https://doi.org/10.1007/ s40265-019-01075-3.

Hannah A. Blair

demail@springer.com

1 Springer, Private Bag 65901, Mairangi Bay, Auckland 0754, New Zealand 